BANCA D'ITALIA

E U R O S I S T E M A

Questioni di Economia e Finanza

(Occasional Papers)

Inflation, debt and the zero lower bound

by Stefano Neri and Alessandro Notarpietro 

13 BANCA D'ITALIA

E U ROS I S T E M A

\section{Questioni di Economia e Finanza}

(Occasional papers)

Inflation, debt and the zero lower bound

by Stefano Neri and Alessandro Notarpietro

Number 242 - October 2014 
The series Occasional Papers presents studies and documents on issues pertaining to the institutional tasks of the Bank of Italy and the Eurosystem. The Occasional Papers appear alongside the Working Papers series which are specifically aimed at providing original contributions to economic research.

The Occasional Papers include studies conducted within the Bank of Italy, sometimes in cooperation with the Eurosystem or other institutions. The views expressed in the studies are those of the authors and do not involve the responsibility of the institutions to which they belong.

The series is available online at www.bancaditalia.it.

ISSN $1972-6627$ (print)

ISSN 1972-6643 (online)

Printed by the Printing and Publishing Division of the Bank of Italy 


\title{
INFLATION, DEBT AND THE ZERO LOWER BOUND
}

\author{
by Stefano Neri ${ }^{\dagger}$ and Alessandro Notarpietro ${ }^{\dagger}$
}

\begin{abstract}
This paper analyses the macroeconomic effects of a protracted period of low and falling inflation rates when monetary policy is constrained by the zero lower bound (ZLB) on nominal interest rates and the private sector is indebted in nominal terms (debt-deflation channel). In this scenario, even cost-push shocks that in normal circumstances would reduce inflation and stimulate output are found to have contractionary effects on economic activity, especially when the interplay of ZLB and debt deflation is considered.
\end{abstract}

JEL Classification: E21, E31, E37, E52.

Keywords: Zero lower bound, monetary policy, disinflation, debt-deflation channel.

\section{Contents}

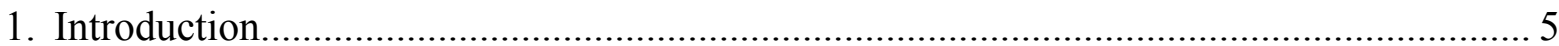

2. Disentangling the effects of a negative shock to inflation............................................... 8

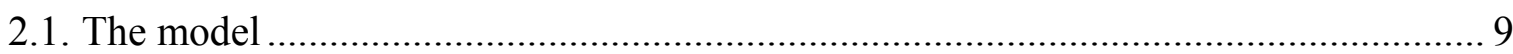

2.2. A negative cost-push shock under normal conditions ........................................ 10

2.3. A negative cost-push shock at the zero lower bound ................................................. 12

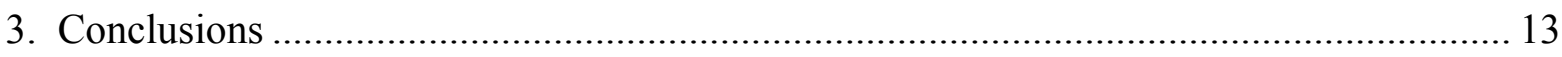

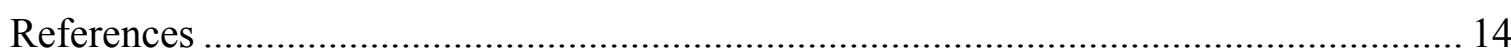

$\dagger$ Bank of Italy, Economic Outlook and Monetary Policy Directorate. 

An unexpected period of low inflation and low nominal income results in a higher actual and expected future real debt burden. Unless compensated for by expectations of higher future income, firms may reduce investment and households consumption. Banks may in turn respond to this situation with stricter credit standards, which reinforces disinflationary pressure and hence worsens debt burdens. This is fertile ground for a pernicious negative spiral, which then also affects expectations.

Mario Draghi, President of the ECB ${ }^{1}$

\section{Introduction}

Euro-area inflation reached a minimum of $0.3 \%$, measured in annual terms, in September 2014 (Figure 1) ${ }^{2}$ core inflation was as low as $0.8 \%$, down from $0.9 \%$ in August. According to the September 2014 ECB staff macroeconomic projections (MPE), annual HICP inflation will be $0.6 \%$ in 2014, 1.1\% in 2015 and $1.4 \%$ in 2016, in a context of a broad-based weakness of the economy, a high degree of unutilised capacity and subdued money and credit creation. The Survey of Professional Forecasters that are periodically polled by the ECB provides a similar picture; the results for the third quarter of 2014 shows that the probability that inflation will stay below $1.4 \%$ in 2016 is assessed to be about 48\%, 13 p.p. higher than in January.

Figure 1. HICP Inflation in the euro area and contribution of components (monthly data; 12-month percentage changes and percentage points)

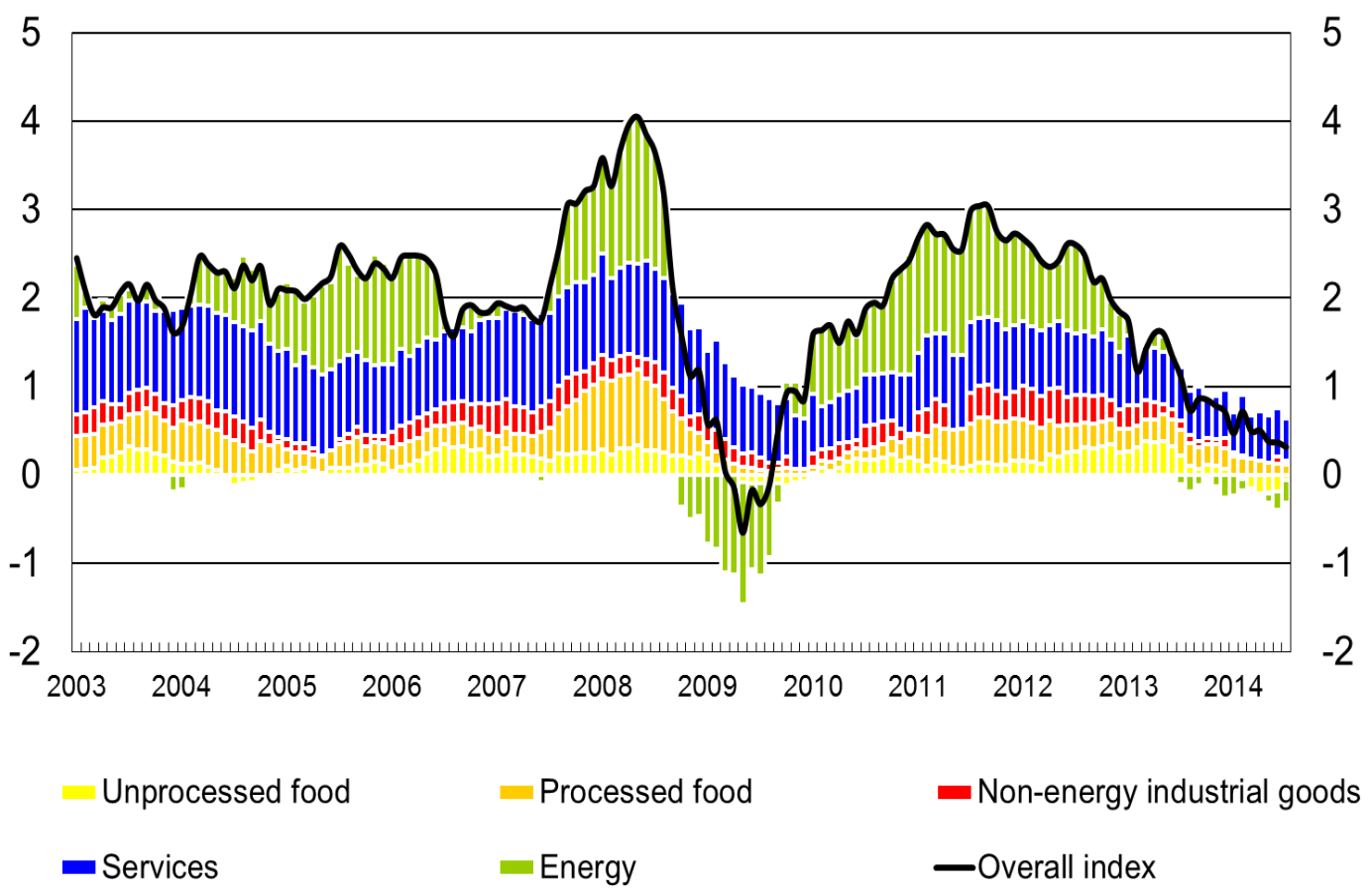

\footnotetext{
1 "Monetary policy in a prolonged period of low inflation", speech by Mario Draghi, President of the ECB, at the ECB Forum on Central Banking, Sintra, 26 May 2014.

${ }^{2}$ A lower value had only been reached in the summer of 2009 . However, on that occasion inflation reflected the effects of rapidly falling oil prices.
} 
Against this background of falling inflation, in the course of 2014 the Governing Council reduced the rate on the main refinancing operations (MRO) by 20 basis points (after having reduced it by 50 basis points in the previous year), to 0.15 in June and to 0.05 in September. The reaction of the nominal 3-month money market rate was limited, since in a context of ample excess liquidity it is anchored to the rate on the deposit facility; the latter was lowered to $0.00 \%$ in July 2012, to -0.10 in June 2014 and to -0.20 in September. The real 3-month money market rate, which was -1.4\% in June 2013 (when inflation stood at $1.6 \%$ ), increased to $-0.2 \%$ in September 2014 , mainly reflecting the decline in expected inflation (Figure 2).

Figure 2. Nominal and real short-term money market rate (monthly data and percentage points)

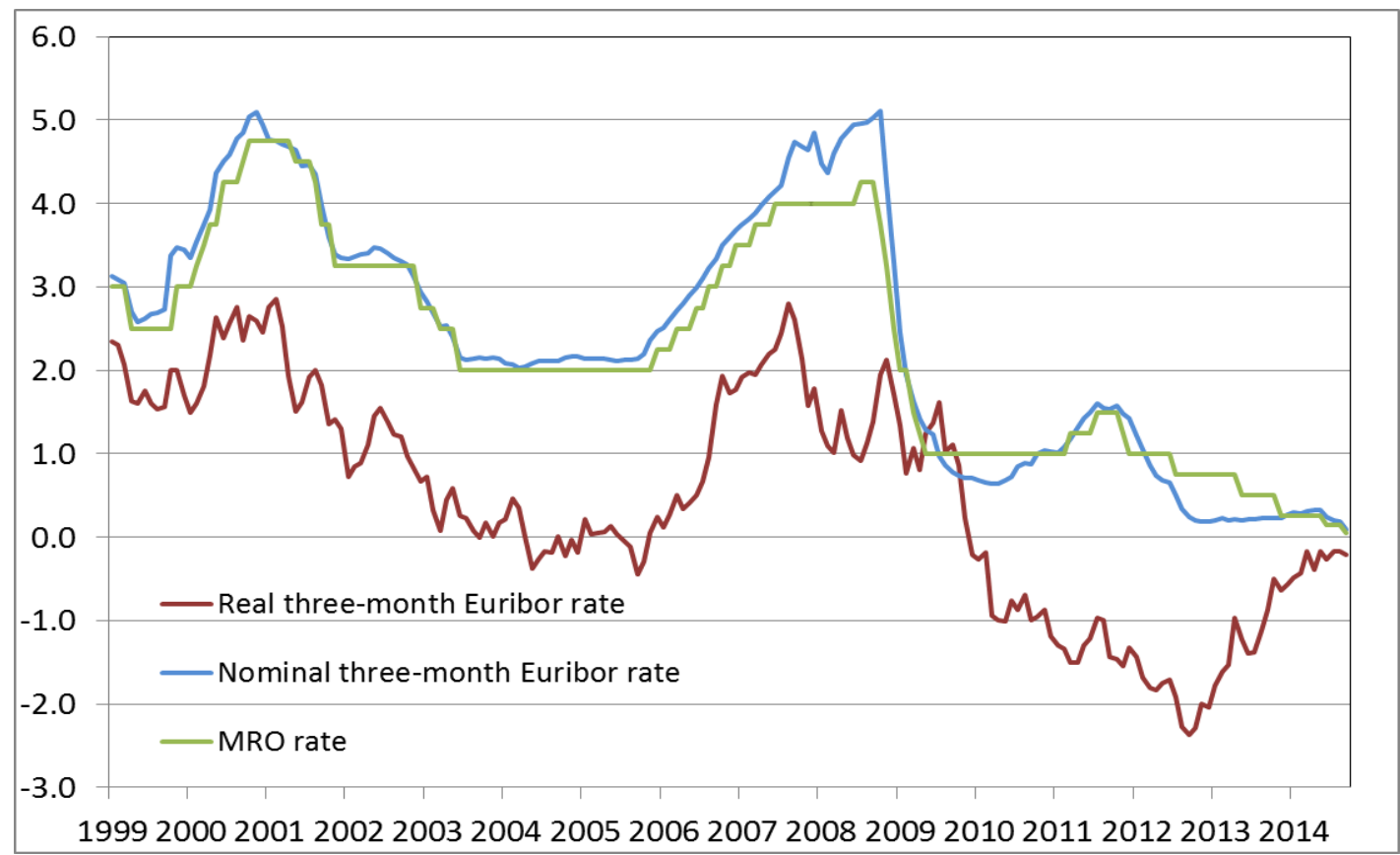

Note: the real rate is computed as the nominal Euribor rate minus one-quarter ahead inflation expectations from Consensus Economics (linearly interpolated at monthly frequency).

With low and decreasing inflation expectations, the short-term real interest rate is likely to get closer to zero, implying increasingly less accommodative monetary conditions. Moreover, since the overall size of euro-area private sector debt as a share of nominal GDP has remained broadly constant at a high level since 2009 (Figure 3), increasing real rates would imply higher real repayment costs for borrowers, thus weighing on the euroarea economic recovery. 
Figure 3. Real interest rate and private sector debt

(quarterly data)

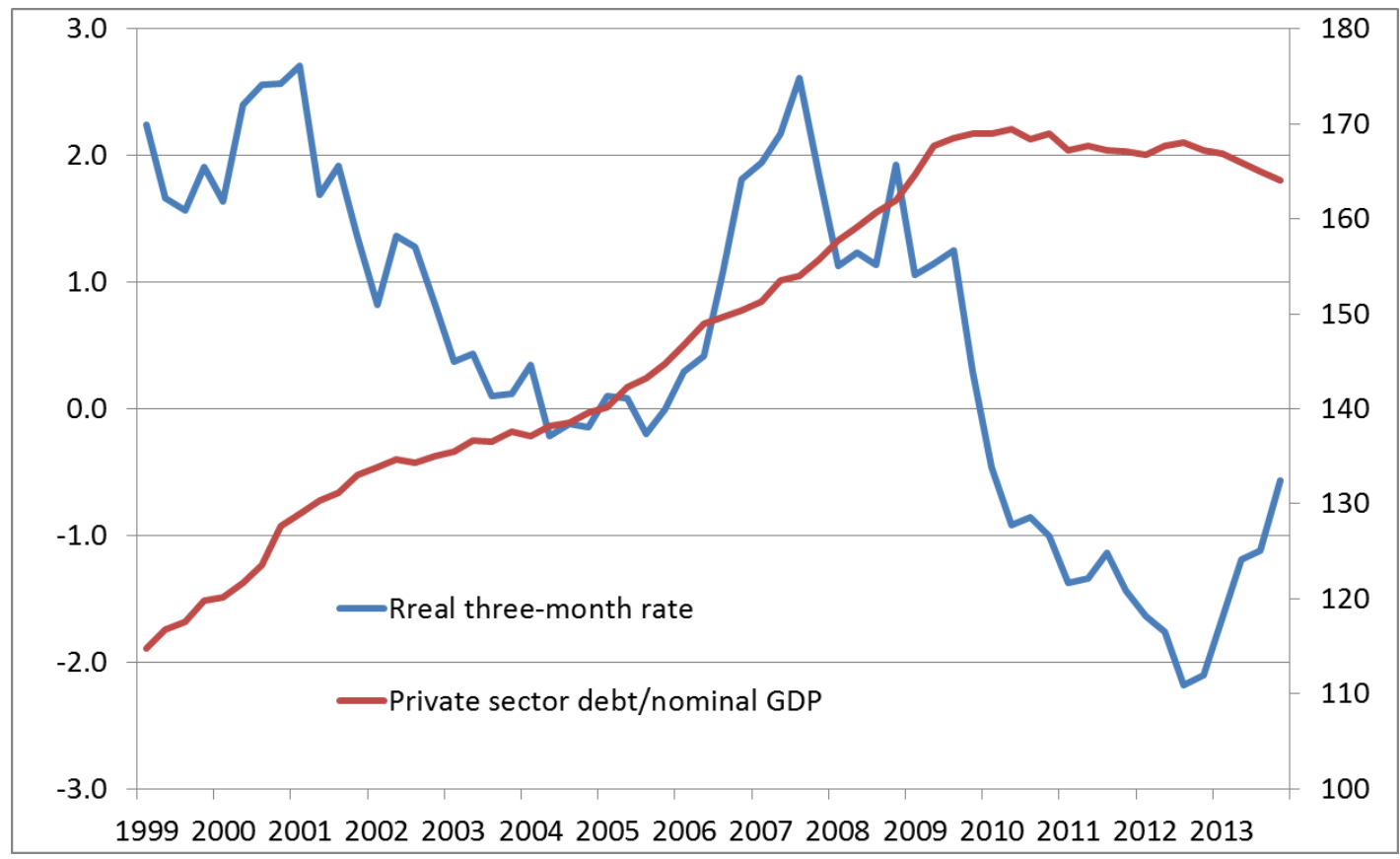

This paper analyses the macroeconomic effects for the euro area of a protracted period of low and declining inflation rates, taking into account the proximity of policy rates to their effective zero lower bound and the high level of private sector debt.

In principle, the effects on the real economy of a fall in inflation may be both positive and negative. On the positive side, a lower inflation rate may support real income, just as higher inflation reduces it: "low inflation [...] supports the real disposable income especially of those people who have a fixed nominal income" (President Draghi, Introductory Statement, 8 May 2014). ${ }^{3}$

The list of negative consequences is, on the contrary, much longer. ${ }^{4}$

First, by moving the economy (closer) to the zero lower bound on nominal interest rates, a protracted fall in inflation reduces the room for conventional, accommodative monetary policy interventions by the central bank.

Second, lower inflation can hamper adjustments in the labour market. While a sufficiently high inflation rate facilitates the adjustment of real wages, low inflation may hamper it (Tobin, 1972). This is due to the downward rigidity of nominal wages; evidence of such asymmetry can be found, e.g., in the report of the Wage Dynamics Network

\footnotetext{
${ }^{3}$ An analogous argument was used in 2008 when inflation was at $4.0 \%$ and the ECB policy rates were raised to prevent second-round effects of surging energy prices and to keep inflation expectations well anchored to the definition of price stability: "[...] unemployment rates have fallen to levels not seen for 25 years. However, these developments, which support household disposable income and consumption, are unlikely to fully compensate the loss of purchasing power caused by higher energy and food prices" (President Trichet, Introductory Statement, 3 July 2008).

${ }^{4}$ Bank of England (2009) provides a summary of the costs of deflation.
} 
(WDN) of the Eurosystem. Both micro data and the survey carried out by the WDN point to the existence of significant downward rigidity in base wages in the EU countries. ${ }^{5}$

Third, lower inflation interferes with private sector debt deleveraging: "[...] with low inflation, the real value of [...] debt does not go down as fast as it would if inflation were higher, so it makes the adjustment of the debtors, the deleveraging, more difficult" (President Draghi, Introductory Statement, 8 May 2014). Since debt contracts are usually fixed in nominal terms, a fall in inflation increases the real debt burden for borrowers in terms of principal repayment and interest payments, and induces the private sector to reduce its amount of debt, leading to a fall in asset prices. In turn, private sector's net worth collapses, leading to a decrease in output and a further fall in inflation - which may quickly turn into deflation - and to a contraction in lending, thus generating a downward spiral. Such mechanism is known as the debt-deflation channel (Fisher, 1932, 1933).

Fourth, if inflation remains low for too long, inflation expectations may de-anchor from the target: "[...] the longer is the period, the bigger are the risks for a de-anchoring of inflation expectations" (President Draghi, Introductory Statement, 8 May 2014). While this risk may still be perceived as low, the probability that inflation will be below 1.5 per cent in five years increased from 0.1 in the second quarter of 2007 to 0.3 in the third quarter of 2014.

The debt-deflation channel and the risk of de-anchoring of inflation expectations may interact and result in a potentially dangerous spiral, as President Draghi's quotation in the Introduction shows.

The analysis in this paper focuses on two of the channels through which a fall in inflation exerts a negative impact on the real economy: the zero lower bound (ZLB) and the debt-deflation channel. The simulations are carried out with a simplified version of the model developed in Gerali, Neri, Sessa and Signoretti (2010). ${ }^{6}$

\section{Disentangling the effects of a negative shock to inflation}

This section illustrates the responses of the economy to a negative cost-push shock to the inflation rate. The nature of the shock is such that it may or may not be accompanied by a fall in economic activity. ${ }^{7}$ This choice is based on two considerations. First, it resembles the current situation in the euro area, in that a sequence of negative surprises to releases on consumer prices has resulted in falling inflation, while at the same time economic activity has been slowly recovering until the first quarter of 2014. Second, that shock encompasses consumer price movements that are not related to the output gap but are due, for instance, to the dynamics of energy and commodity prices; the current prolonged decline in inflation is indeed partly due to the moderation in the price of commodities in euro (see Figure 1$)^{8}$

\footnotetext{
${ }^{5}$ ECB, "Wage dynamics in Europe - Final report of the Wage Dynamics Network", 2009.

${ }^{6}$ The model was estimated with Bayesian methods using euro-area data for the period 1998 Q1-2009 Q1.

${ }^{7}$ Specifically, the shock enters as a negative additive term in the log-linearized Phillips curve, moving inflation and output in opposite directions. Hence, it is intrinsically different from a negative aggregate demand shock, which would imply a contraction of economic activity.

${ }^{8}$ Using a negative demand shock to conduct the simulations would strengthen the interaction between the zero lower bound and the debt-deflation mechanism.
} 
Under normal conditions, a cost-push shock such as the one considered here drives inflation and output in opposite directions and temporarily modifies the trade-off facing the central bank between stabilizing the inflation rate and closing the output gap. A negative cost-push shock raises real disposable income and allows consumers to buy more goods, resembling a positive supply shock that drives inflation below its steady-state level. In normal circumstances, the central bank can easily contrast the latter development by adjusting the policy rate. When this cannot be done because the ZLB is binding, the debtdeflation mechanism may result in a negative reaction of economic activity, as shown by the simulations below. ${ }^{9}$

In order to illustrate how the transmission of a negative inflation shock is affected by the state of the economy, the following cases are considered. First, it is assumed that the central bank can freely adjust the nominal interest rate in response to the shock. Second, the impulse responses of the main macroeconomic variables are compared to those obtained when all debt contracts are indexed to the inflation rate, so that unexpected changes in inflation do not affect the real cost of servicing debt. ${ }^{10}$ The comparison aims at highlighting the relative contribution of the debt-deflation channel to the transmission of the shock. Third, it is assumed that the central bank is constrained by the ZLB, so that the policy rate can be barely reduced after the shock. Finally, also in the latter case the response of the economy with indexed debt contracts is investigated.

The simulations carried out in this note are meant to be only illustrative and do not provide a necessarily accurate quantification of the macroeconomic effects of a declining inflation rate in the euro area in the current situation. However, they clearly show that the interaction between the debt-deflation channel and the ZLB is likely to result in a negative cost-push shock to inflation having contractionary effects on the economy.

\subsection{The model}

The economy is composed of three types of agents: patient households, impatient households and entrepreneurs. Impatient households and entrepreneurs act as net borrowers, facing borrowing constraints that link the value of their collateral (housing and the capital stock, respectively) to the maximum amount of funds they can obtain from patient households (the savers). ${ }^{11}$ Debt is issued in the form of one-period contracts. When debt contracts are fixed in nominal terms, unexpected changes in inflation cause expost fluctuations in the real interest rate paid by borrowers. The economy features nominal and real rigidities. ${ }^{12}$ Monetary policy is set by the central bank; in normal times it adjusts the policy rate according to a Taylor-type rule that is a function of quarter-on-quarter output growth and inflation.

\footnotetext{
${ }^{9}$ Recent research explores the effects of negative inflation shocks at the ZLB. Wieland (2014) empirically tests the prediction that negative oil supply shocks are contractionary at the ZLB.

${ }^{10}$ See lacoviello (2005) for the details on how to neutralize the debt-deflation and the asset price channels in a model with borrowing constraints.

${ }^{11}$ In order to simplify the analysis, the model does not include a banking sector, but rather assumes that lenders directly finance borrowers.

12 Nominal rigidities are introduced in the form of price and wage stickiness and indexation to inflation. Real rigidities include habit formation in consumption and adjustment costs on investment.
} 


\subsection{A negative cost-push shock under normal conditions}

Figure 4 reports the responses of inflation and the policy rate to a negative inflation shock (green line; all results are in terms of deviations from the baseline, which coincides with the steady-state).

Figure 4. Response of inflation and policy rate
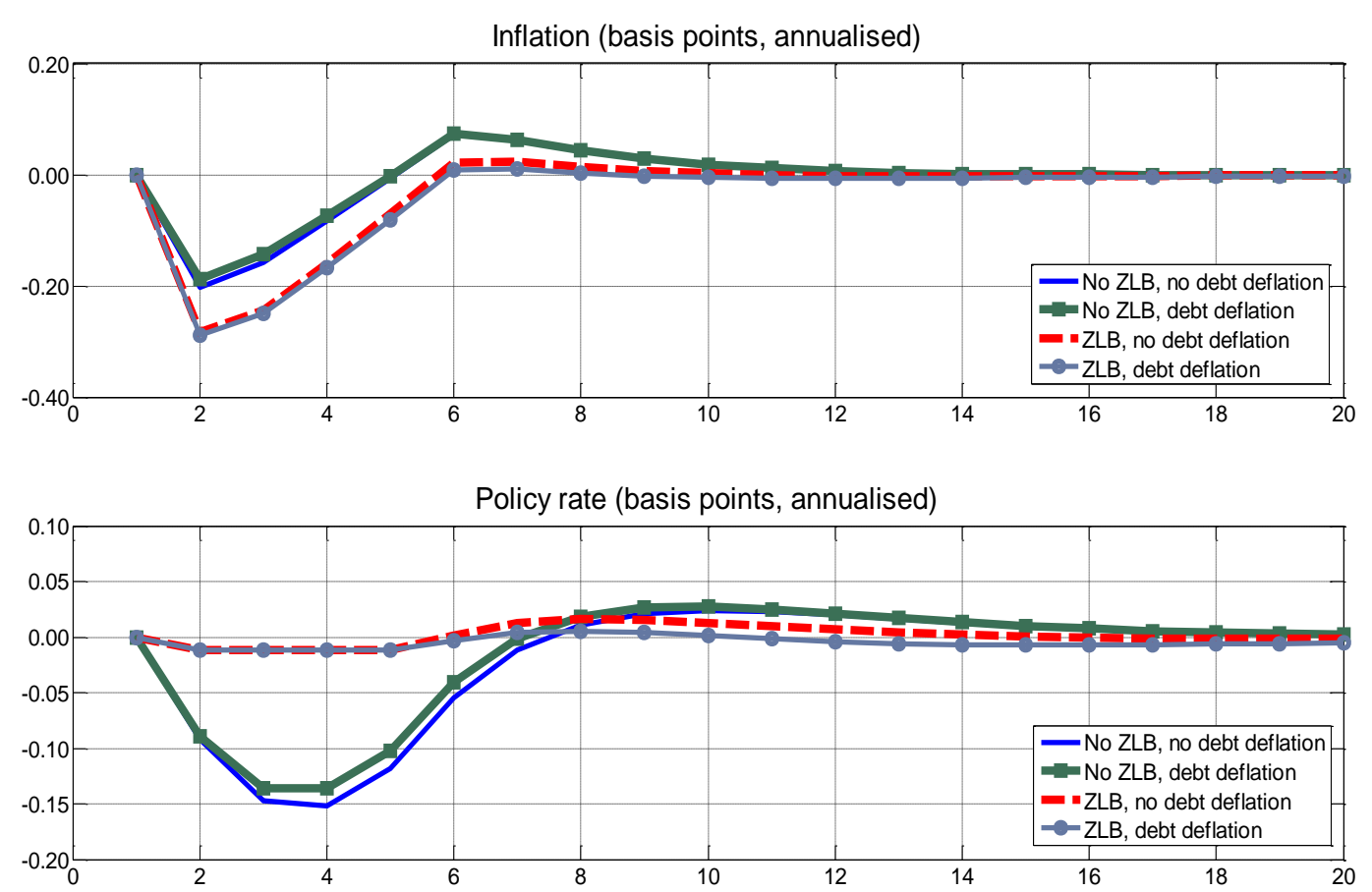

Inflation falls on impact by between 20 and 30 basis points and gradually returns to steady state. The central bank lowers the policy rate and the real interest falls. Consumption, investment and output rise above their steady-state levels for more than two years (Figures 5 and 6 ). With debt contracts indexed to the inflation rate (blue line), the effects of the shock are qualitatively similar; the response of consumption and output is somewhat more front-loaded (Figures 5 and 6 , solid blue line). The difference is due to the redistribution effect induced by the change in inflation: with nominal debt contracts, the initial fall in inflation results in a transferring of wealth from the borrowers to the lenders, who are more patient and do not immediately increase consumption and investment. Therefore, when debts contracts are indexed, the response of consumption and investment is more rapid. The initial increase in output is larger and the response of the demand components is less persistent. 
Figure 5. Responses of consumption and investment
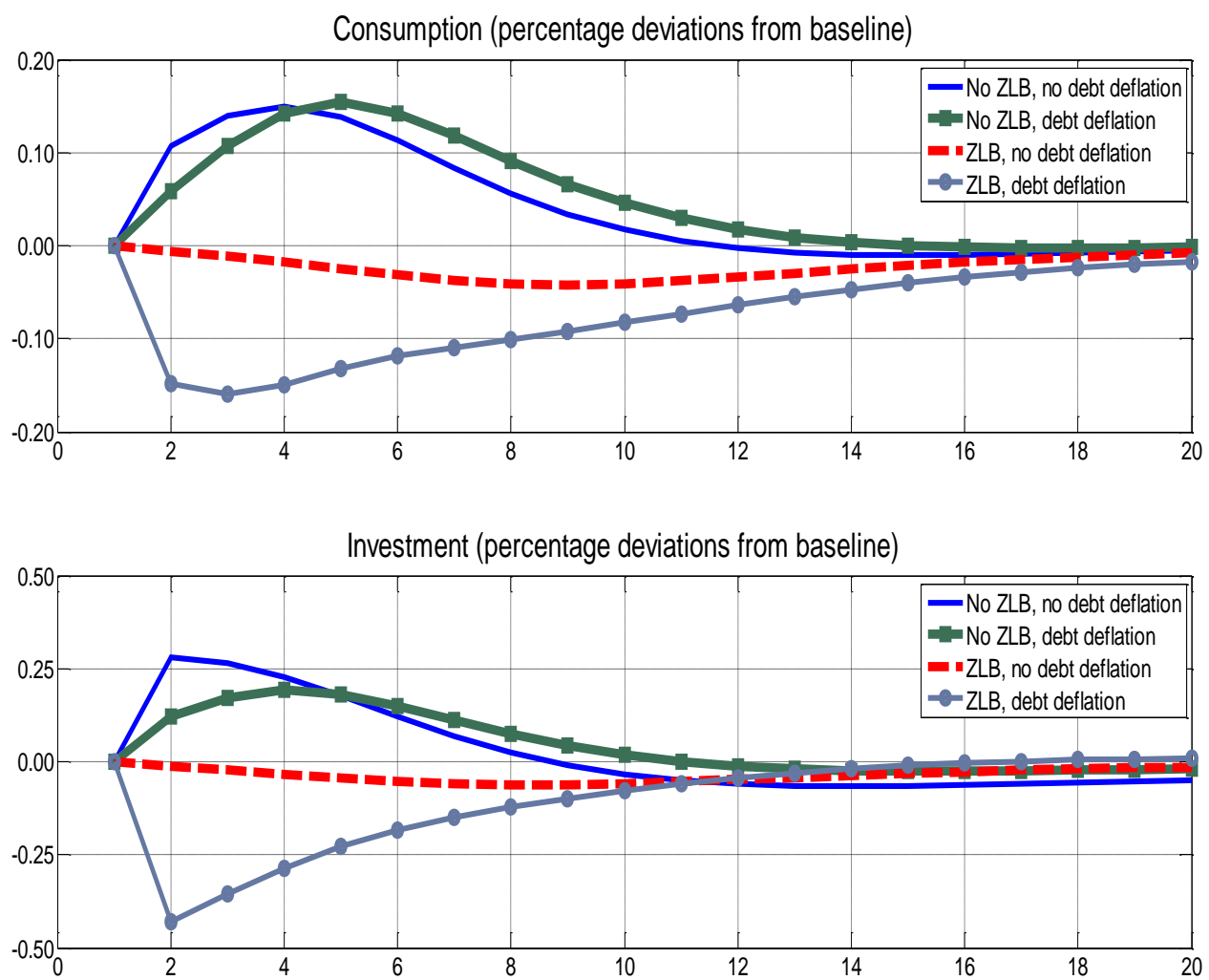

Figure 6. Response of output

Output (percentage deviations from baseline)

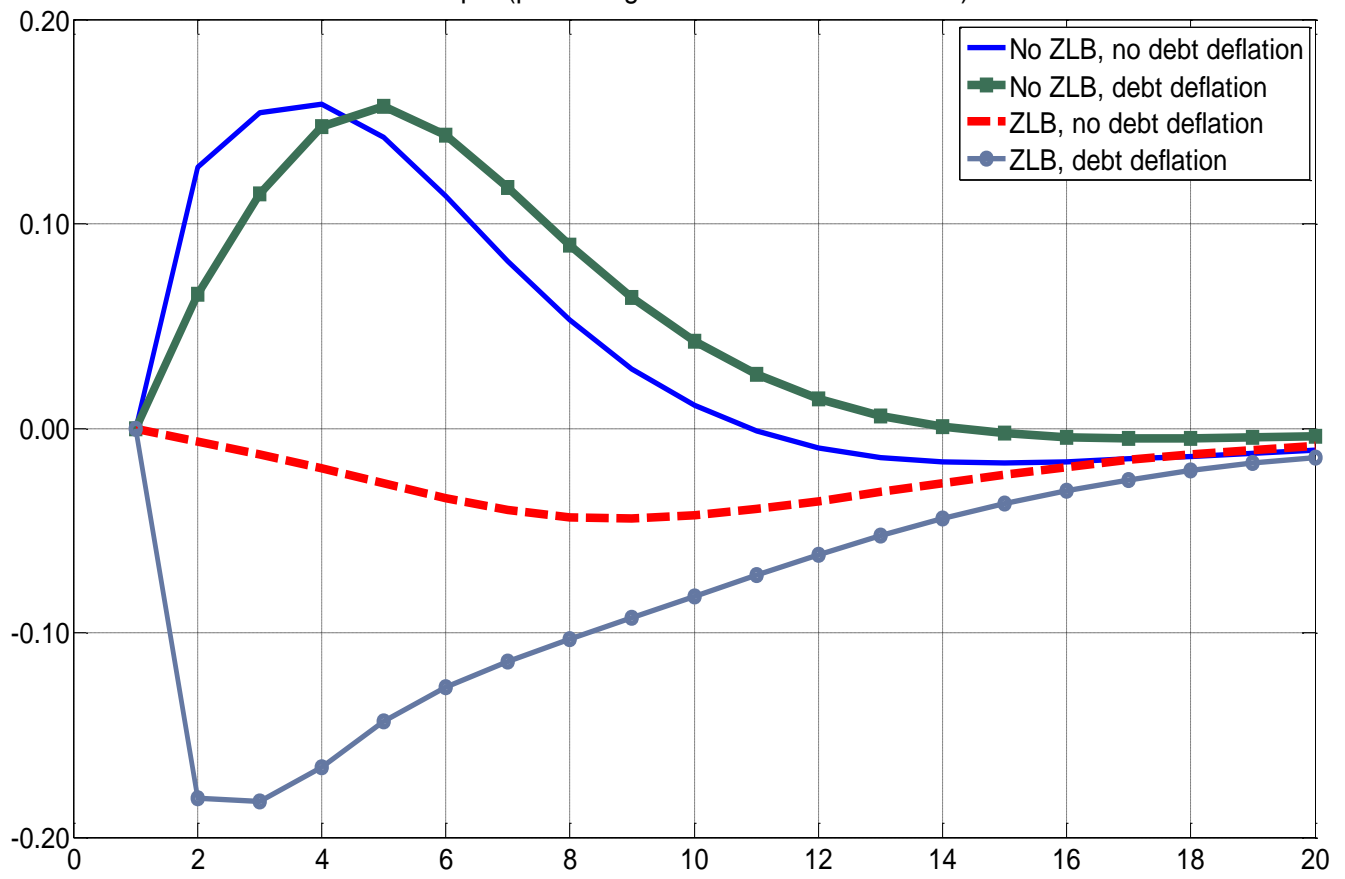




\subsection{A negative cost-push shock at the zero lower bound}

This subsection considers the case in which the central bank cannot adjust the policy rate in response to the shock. Short-term rates are assumed to be at very low levels, so that the room for further downward adjustment is almost nil. Given the ZLB, the real interest rate increases after a negative cost-push shock, thus counteracting the expansionary effects on aggregate demand of the decrease in the price level. The debtdeflation channel operates as an amplification mechanism: the higher real level of debt and the real repayment cost reduce the disposable income of the borrowers and induce a fall in asset prices and in the value of collateral, resulting in an acceleration of the deleveraging process.

In such circumstances, consumption and investment fall, reflecting the transfer of wealth from borrowers to lenders (Figure 5, grey line). The overall effect on output becomes negative (Figure 6), as opposed to what is observed when the central bank can lower the policy rate. If debt contracts are indexed to the inflation rate, the effects on output are still negative but comparatively small (Figure 6, dashed red line): the real value of outstanding debt remains unchanged. However, the higher real interest rates still reduce aggregate demand, inducing a fall in asset prices and a decline in the value of collateral.

A clear message emerges from these simulations. A shock that drives inflation and output in opposite directions when the interest rate is free to react can instead induce a fall in both variables at the ZLB. In addition, the combination of the ZLB with the debt-deflation channel amplifies the contractionary effects on economic activity.

Some observations are in order.

First, the assumption of one-period debt contracts implies that all existing debt is rolled over in each period and the issuance of new bonds immediately adjusts to the shock. With longer debt maturities, the effects of a negative inflation shock on economic activity may be stronger and more persistent. ${ }^{13}$

Second, the model does not include the possibility of default for borrowers. Therefore, unexpected variations in the real cost of servicing debt only affect consumption and investment decisions, but do not trigger any choice over debt restructuring. Including the latter may imply that prolonged periods of falling inflation rates at the ZLB would increase the probability of default, so that the contractionary effects of the initial shock could be further magnified.

Finally, two features of the model are particularly relevant for the transmission of the shock. On the nominal side, the presence of downward wage rigidity may alter the impact of the shock and modify the response of inflation and output. A sensitivity analysis was performed by varying the degree of nominal wage stickiness in the simulations where the debt-deflation channel is at work and monetary policy is constrained by the ZLB. The baseline case (in which wages are adjusted every 5 quarters) is compared to an alternative set up in which the adjustment takes place every 2 quarters. The effects of

\footnotetext{
${ }^{13}$ See Andrés, Arce and Thomas. (2014) for an analysis of the role of multi-period debt contracts and slow debtdeleveraging at the ZLB.
} 
varying the degree of nominal wage rigidity are limited. A thorough modelling of downward wage rigidities may possibly shed more light on this issue. ${ }^{14}$ On the real side, a relevant role is played by the degree of private sector indebtedness. Two parameters are particularly relevant: the loan-to-value (LTV) ratios and the relative share of indebted agents in the economy. A sensitivity analysis was carried out by varying these two parameters. The results of the simulations remain valid. Clearly, with a lower LTV ratio, the deleveraging effect induced by the shock has a smaller impact on the economy; both inflation and output fall by a smaller amount compared to the baseline case. Analogously, a smaller share of indebted agents in the economy acts reduces the amplification effects.

\section{Conclusions}

This paper has illustrated the possible macroeconomic consequences of a prolonged period of falling inflation when the economy is close to the zero lower bound (ZLB) on nominal interest rates and the private sector is indebted in nominal terms. The interaction of the ZLB and the debt-deflation channel can turn upside down the implications of a "good" shock, i.e., a shock that in normal circumstances would lower the inflation rate and expand economic activity.

The result is obtained in a very stylized setup, where financial intermediation plays no role. The inclusion of a banking sector may help shed some light on the dynamics of credit supply in a period of low and falling inflation rates and on the related macroeconomic effects. We leave the investigation of these issues, as well as the role of downward wage rigidity, to future research.

\footnotetext{
${ }^{14}$ See Fahr and Smets (2010) on the role of downward wage rigidity in a monetary union.
} 


\section{References}

Andrés J., O. Arce, and C. Thomas (2014), "Structural reforms in a debt overhang, Banco de Espana, working paper n. 1421.

Bank of England (2004). "Deflation”, Quarterly Bulletin 2009 Q1.

ECB (2009). "Wage dynamics in Europe - Final report of the Wage Dynamics Network".

Fahr, S. and F. Smets (2010). "Downward Wage Rigidities and Optimal Monetary Policy in a Monetary Union", The Scandinavian Journal of Economics, Vol. 112, issue 4, pp. 812840 .

Fisher, I. (1932). Booms and depressions. Some first principles, London: Allen and Unwin.

Fisher, I. (1933). "The debt-deflation theory of great depressions", Econometrica, Vol. 1, issue 4, pp. 337-357.

Gerali, A., S. Neri, L. Sessa and F. M. Signoretti (2010). "Credit and Banking in a DSGE Model of the Euro Area", Journal of Money, Credit and Banking, Vol. 42, s1, pp. 107-141.

lacoviello, M. (2005). "House Prices, Borrowing Constraints and Monetary Policy in the Business Cycle", American Economic Review, Vol. 95, No. 3, pp. 739-764.

Tobin, J. (1972). "Inflation and Unemployment", American Economic Review, Vol. 62, issue 1, pp. 1-18.

Wieland, J. (2014). "Are Negative Supply Shocks Expansionary at the Zero Lower Bound?', University of California, San Diego, mimeo, 